\title{
St. Thomas and the Divine Origin of Law: Some Notes
}

\author{
Santo Tomás y el origen divino de la ley: algunas \\ anotaciones \\ Recibido: 6 de octubre de 2008 - Revisado: 28 de octubre de 2008 - Aceptado: 2 de noviembre de 2008
}

Lawrence Dewan, O.P.*

\section{Resumen}

En este estudio se presenta una serie de anotaciones sobre el concepto de ley y su relación con Dios en la antigüedad clásica, específicamente tomando los puntos de vista de Aristóteles y Santo Tomás de Aquino.

Palabras clave

Derecho, Filosofía, Teología, Summa Theologica.

\begin{abstract}
This article presents a series of notes on the concept of Law and its relationship to God in Classical Antiquity, specifically taking into account the viewpoints of Aristotle and Saint Thomas Aquinas.

Key words

Law, Philosophy, Theology, Summa Theologica.
\end{abstract}

" Profesor de Filosofía y Teología en el Colegio Dominicano de Ottawa y como profesor adjunto del Departamento de Filosofía y miembro de la Facultad de Postgrados y Estudios Postdoctorales de la Universidad de Ottawa. 
Human life is a social life, and law is one of its most essential features. It is a rational ordering of that life. That law exists is evident, but there is room for exploration of its nature and causes. The theory of law, or the knowledge of the foundations of law, pertains to metaphysics or primary philosophy. Why this is so we can gather from an observation of Aristotle near the beginning of his treatise The Parts of Animals. $\mathrm{He}$ is there teaching about the nature of physical science or "philosophizing about nature," and is stressing the importance of studying the nature of the form of the thing, and not merely the matter. In the study of living things, that form is called a "soul." But he then raises the question: whether the "whole" soul or only some "part" of it comes within the province of natural science? And the answer runs:

Now if it be of the whole soul that this should treat, then there is no place for any other philosophy beside it. For as it belongs in all cases to one and the same science to deal with correlated subjects - one and the same science, for instance, deals with sensation and with the objects of sense - and as therefore the intelligent soul and the objects of intellect, being correlated, must belong to one and the same science, it follows that natural science will have to include the whole universe in its province. But perhaps it is not the whole soul, nor all its parts collectively, that constitutes the source of motion; but there may be one part, identical with that in plants, which is the source of growth, another, namely the sensory part, which is the source of change of quality, while still another, and this not the intellectual part, is the source of locomotion. I say not the intellectual part; for other animals than man have the power of locomotion, but in none but him is there intellect. Thus then it is plain that it is not of the whole soul that we have to treat. For it is not the whole soul that constitutes the animal nature, but only some part or parts of it. (Aristotle, On the Parts of Animals, translated in 1882, ๆ 1.I.).

By "the animal nature" here, Aristotle is referring to that which all animals have in common. What is proper to the human animal as human is omitted from natural science. The human being, by virtue of intellect, is seen here as related to the whole of reality. Aristotle is clearly of the view that only metaphysics, the science whose range includes all things, ${ }^{1}$ can adequately study the human being as to what is proper to that being.

Now, law pertains to humans and is proper to rational or intellectual substances. ${ }^{2}$ It is only by determining the proper place of the human mind within the whole of reality that we will understand law, viewing it in the context of its foundations. Let us call this "the sapiential vision of law."

That all law has a divine origin is a doctrine not difficult to find in the writings of Thomas Aquinas. At Summa Theologica (hereinafter ST) 1-2.93.3 the explicit point is that all law derives from the eternal law, eternal law which has already been explained as "the plan of divine wisdom inasmuch as it is directive of all acts and movements." (St. Thomas, Summa Theologica, ब1 1-2.93.1).

Prior to this, the locating of the discussion on law, within the moral part of the $S T$, already suggested this doctrine. The $S T$, and in general the work of St. Thomas, is meta-philosophical. It is a study and teaching of what has been revealed to us by God himself, and thus surpasses mere human wisdom, i.e. philosophy. However, revelation presupposes the order of nature, and Thomas's teaching envelops philosophy rather than excluding it. (St. Thomas, Summa Theologica, -1.2.2.ad 1).

In the 1-2, the more summary overall picture of the moral order, the treatment begins with beatitude, the ultimate goal of human life, as something whose attainment depends in a measure on human action (St. Thomas, Summa Theologica, I 1-2.5.7); it then speaks of that action, its principles within the human agent, viz. the virtues; and finishes with the extrinsic principles of that action, primarily God. So presented, God is seen as guide by virtue of law and support by virtue of grace. ${ }^{3}$ Law thus is presented as a divine influence. One might think that this means merely that some special sort of 
law, the "divine law" specially revealed to us by God, is such a help. As the 1-2 carefully develops the overall causal picture, one sees that "law" names a reality found according to priority and posteriority, flowing from the divine intellect and will, and remaining, wherever properly found, a rational participation in that divine reality.

Thomas begins with a general presentation of the essence of law, and does so by considering primarily law as human beings make it. His general definition is:

... [law] is nothing other than an ordering by reason towards the common good, promulgated by one who has responsibility for the community. (St. Thomas, Summa Theologica, $\mathbb{1 1 - 2 . 9 0 . 4 ) .}$

Once this is done, he presents the variety of kinds of law: eternal, natural, human, and divinely revealed laws. ${ }^{4}$

As already mentioned, eternal law is the plan of direction of the universe present within God himself. It is thus identical with God himself (St. Thomas, Summa Theologica, 1-2.9.1.1 ad. 3). This obliges us to reflect on the sort of unified field the general term "law" names. Early in the $S T$, i.e. q. 13 of the first part, Thomas explained the way in which human language bears upon divine things. This is the doctrine of "the divine names." What do we mean when we say the words "good" or "wise" of God? We learn that it is through a sort of analogy that "good" is said of God. To say: "God is good" is not to say merely that God is the cause of the goodness of creatures, or merely that God is "not bad." Rather, we mean that what we call "goodness" in creatures exists by priority, in a higher way, in God (St. Thomas, ST, 1 1.13.2). Thus, as regards the reality named, it is found more truly in God than in creatures, whereas the name applied is applied first to that which is found in creatures, and has the mode of signifying appropriate for creatures. (St. Thomas, ST, 1 1.13.6).

All this surely applies to "law" as well. It is a word invented to name the human reality, but it is said properly of the eternal law which is in God, and indeed that is what most of all deserves the name "law". 5

The presentation of eternal law gives the most dominating metaphysical vision of the domain of law. We then can see the way that, within the life of the rational creature which is man, there is a root of all man's law-making, a root in what is called "natural law." (St. Thomas, ST, 1 1-2.95.2.)

Presenting eternal law, in ST 1-2.91.1, St. Thomas immediately recalls the presentation of divine providence in $S T$ 1: We read:

... law is nothing else than a dictate of practical reason in the leader who governs some perfect community. Now, it is evident, given that the world is ruled by divine providence, as was had in book 1 , that the whole community of the universe [communitas universi] is governed by divine reason. And therefore the very plan [ratio] of the government of things present in God as in the governor [principe] of the universe has the intelligible note [ratio] of law. And because divine reason [ratio] conceives [concipit] nothing temporally, but rather has an eternal concept [habet aeternum conceptum], as is said in Proverbs $8.23,{ }^{6}$ one ought to call such law "eternal"

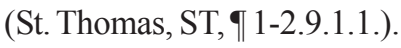

Providence was discussed in $S T$ 1.22, and the full sapiential vision of law must include that teaching. In my brief presentation today, I wish to focus on one feature of the doctrine of natural law. Natural law is presented as the rational creature's participation in the eternal law (St. Thomas, ST, 1-2.9.1.2.) It is properly called "law," something that cannot be said of the eternal law's participation by lower, non-rational creatures. Natural law is properly law because of the human being's participation in providence, as rationally providing in some measure for himself. ${ }^{7}$ We are not, of course, the source of the legislation; rather, it is in us as in those who are ruled and measured

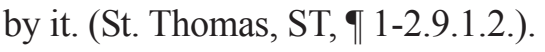

Natural law is possessed by the human being primarily through the vision of what goodness is, 
a vision which attests to our immediate relation to the universal cause of being and goodness. ${ }^{8}$ What is primary in Thomas's presentation of law is its being rational, an expression of reason ( $\mathrm{St}$. Thomas, ST, I 1.2-90.1.) The vision of that reasonableness is the source of the obligation it presents to us. ${ }^{9}$ However, two essential features of law are that it be made by the one responsible for the common good for which it is law, and that it be promulgated to those subject to the law. I take this to mean that law only appears in its adequate reasonableness when it is so promulgated as to reveal its proper origin. This raises the question of natural law's adequate promulgation. And it is this issue that I wish to revisit here today.

So much is it an issue that in the article on the necessity for promulgation of law, in the question on the definition of law, an objection is based precisely on the case of natural law. One finds what is essential to law maximally in natural law, says the objector, and yet it stands in no need of promulgation. To this Thomas replies:

... it is to be said that the promulgation of the law of nature [legis naturae] is from the very fact that God places it within the minds of human beings so as to be naturally known [naturaliter cognoscendam] (St. Thomas, ST, \ 1-2.90.4 ad. 1.)

Now, for this reply to be sufficient, it seems to require that our knowledge of natural law include an appreciation of divine providence as its source.

This is a point on which Suarez insisted in his presentation of natural law (Suarez, 1856a). He explains that the issue is not whether the natural law come from God as author of natural reason, but rather if it comes from him precisely as a legislator. He holds that it comes to us in such a way that we know it is from God as from a legislator. ${ }^{10}$

The ultimate objection to this in Suarez's discussion bears upon the need for God to intimate to the human being what the law is. For law really to be law, there must be, not only the will of the legislator in the matter, but also the intimation or insinuation that that is his will. Here Suarez answers that intimation of the will follows with the same necessity (as he had earlier mentioned), viz. from the perfection of divine providence. And thus the very judgment of right reason naturally inserted in man is the sufficient sign of that divine will, nor is any other insinuation necessary. And he says:

The proof is, that the judgment of reason indicates, just by virtue of itself, divine providence of a sort fitting for God, and morally necessary for his full lordship and due subjection of man to him, in which providence this legislation is contained. Furthermore, for this reason it is known through natural reason that God is offended by sins which are done against natural law, and their punishment pertains to him, and judgment [in their regard]: therefore, the natural light itself is, just by itself, the sufficient promulgation of natural law, not only because it manifests the intrinsic inappropriateness or appropriateness of acts, which the uncreated light of God shows: but also because it intimates to man [hominis, sic; lege homini] that the contrary actions displease the author of the nature, as the supreme Lord, and care-giver, and governor of that same nature: therefore, this is sufficient intimation of that law, as Thomas judges in 1-2.90.4.ad 1 (Suarez, 1856b, p. 112A).

He is referring to Thomas's saying that the promulgation of natural law is sufficient, by virtue of God's inserting it into our minds so that it is naturally known. The point here seems to be that we have by natural reason ${ }^{11}$ some knowledge of a perfect providence, and thus we see our natural knowledge as the expression of a law. ${ }^{12}$

In a previous paper ${ }^{13}$ I sketched an interpretation of Thomas in this regard. Since then Kevin Flannery (2001) has presented a line of thinking on this point based on Thomas's admission that in our natural knowledge of beatitude as the end of life there is included a sort of knowledge of God as himself beatitude (and thus a sort of innate knowledge that God exists). This teaching by 
Thomas occurs where he is arguing that the proposition "God exists" is not known just by virtue of itself to the human mind. He is confronted with the authority of St. John Damascene teaching that there is in us an innate knowledge of the existence of God. He replies:

... it is to be said that to know that "there is a god" in some general way, subject to some confusion, is naturally inserted in us, i.e. inasmuch as God is [what constitutes] the happiness of man; for man naturally desires happiness, and that which is naturally desired by man is naturally known by him. But that is not to know, unqualifiedly, that there is a god, just as to know "someone is coming" is not to know Peter, even though it is Peter who is coming; for many reckon that the perfect good of man, which is happiness, is riches; some [that it is] pleasures; and some something else (St. Thomas, ST, \1.2.1 ad. 1.)

As one can see here, this "knowledge of God" is such just to the extent that "knowledge of someone" is "knowledge of Peter". This hardly seems an adequate basis for arguing the promulgated character of natural law.

Flannery (2001, p. 44) makes his argument in considering the precept of natural law that we are to love God with all our heart. The love of God is described by Thomas as a first and common precept of natural law, known by virtue of itself to human reason, either by nature or by faith; it, together with the second commandment of love of neighbor, is related to the Decalogue as principle to conclusions (St. Thomas, ST, $\mathbf{~} 1$ 2.100 .3 ad. 1). Flannery is taking into consideration the teaching of St. Thomas that the existence of God is a demonstrable conclusion rather than a propo-sition per se nota quoad nos. How, then, can the precept: "love God" be so known? His solution, I would say, amounts to substituting for the precept: "love God" the precept "love happiness" or "seek happiness", on the basis of the teaching of St. Thomas that the existence of God is thus known in a way, in that we have a natural desire for happiness and God is in fact happiness. ${ }^{14}$
This is hardly satisfactory. What we are speaking of are, after all, among the best known items in the domain of practical reason. Consider what is said about the precept to love God above all else. For example:

That which is maximally and firstly natural to man is that he love the good, and most especially the divine good and the good of one's neighbor. ${ }^{15}$

Moreover, it is natural to love God more than ourselves by a friendly love, not merely a concupiscible love; and our love for happiness is merely concupiscible. ${ }^{16}$

Flannery claims to be taking his cue from Thomas commenting on Aristotle's Nicomachean Ethics, as follows:

And it can be said that all men have appetite for the same delight in virtue of natural appetite, though not, nevertheless, according to their own judgment; for not all reckon in their heart nor say orally that the same delight is best; still, nature inclines all to the same delight as to the best, viz. to the contemplation of intelligible truth, inasmuch as all men by nature desire to know. And this happens because all have naturally within themselves something divine, viz. the inclination of nature which derives from the first principle; or else the very form which is the principle of this inclination. ${ }^{17}$

Now this involves moving from whatever people judge and say they find supreme pleasure in to their actually finding supreme pleasure in the contemplation of intelligible truth. However, that move does not take us from what is humanly known intuitively (we desire happiness) to what is known only through demonstration or reasoning (happiness is to be found in God). Thus, it does not really provide a model for what Flannery (2001) is doing with "love happiness" standing in for "love God".

However, Flannery (2001) also makes reference to $S C G 3.38$ (2161) though he does not quote it. ${ }^{18}$ This, in fact, is quite a different doctrine from the one he has featured. It is not 
about an implicit knowledge of God through an actual knowledge of happiness. It is about a remarkable dimension of our natural life, viz. a natural reasoning to a conclusion that God exists. We should not envisage the natural dimension of our cognitive life merely in terms of simple apprehensions of such items as being, unity, act and potency. ${ }^{19}$ We should not even limit the picture to the primary axioms, such as the impossibility for the same thing to be and not be. ${ }^{20}$ Rather, a further dimension of what is naturally conferred on us is our natural reasoning. Three texts come to mind. There is the just mentioned $S C G$ item. There is $S T 2-2.85 .1$, on natural law as requiring the offering of sacrifice to God, and, least known of all, there is Thomas's commentary on Psalm 8, a text from his final academic activity in Naples. ${ }^{21}$

The $S C G$ text occurs in a context where it is already clear that ultimate human happiness consists in a knowledge of God. Thomas is beginning a series of chapters in which various modes of human knowledge of God are considered as possible candidates for such happiness, a series beginning with the most imperfect knowledge. Thus, Thomas speaks of a knowledge had by pretty well everyone, the sort of knowledge of God which has led some thinkers to say that such knowledge is "per se notum". He himself holds that it is really the result of "natural reason" [naturali ratione] proceeding from our experience of the order of natural things to an orderer of natural things. The stress is on the imperfection of the knowledge, the "confused" character of the knowledge. One should note particularly, in the same chapter, that a person who does not have such knowledge is morally blameworthy. Thus, it is knowledge very much linked to our common membership in the moral order.

While the $S C G$ text relates the reasoning to our experience of "the order of natural things", the ST 2-2 text is more closely linked to our experience of our own imperfection. We read:

... natural reason [naturalis ratio] declares forcefully $[$ dictat $]$ to man that he is placed under some superior [being], because of the defects which he experiences in himself, with regard to which he needs to be aided and directed by some superior. And whatever that [superior] is, this it is which among all [men] is called "a God". But just as, in natural things, the lower are naturally placed under the higher, so also natural reason strongly declares to man, in accordance with natural inclination [naturalis ratio dictat homini secundum naturalem inclinationem], that he [should] exhibit, in a way in keeping with his own self, submission and honour to that which is above man (St. Thomas, ST, $\uparrow$ 2-2.85.1).

Here the resulting precept is not precisely the love precept, but rather pertains to the virtue of religion, the highest form of justice (St. Thomas, ST, I 2-2.122.1.) Nevertheless, what interests us is the nature of the knowledge of God that is involved, the fruit of natural reasoning. And it is seen as universal, i.e. pertaining to man by his very nature.

Lastly, and in many ways most impressively, we have the comment on Psalm 8, speaking of the manifest character of the divine greatness, seen by mere "infants". There had previously been mention in the psalm of the majesty of God. Thus, Thomas says:

Then, when he says: Out of the mouth [ex ore], he shows that it [the majesty of God] is maximally manifest. And firstly he shows the manifestness; secondly the reason for it, there [where he says]: Because I will see [Quoniam videbo].

That it is manifest he proves: because that is manifest which is placed within [inditum] all, no matter how simple [they are], as by a sort of natural knowledge [quasi quadam naturali cognitione]. For there are two sorts of men who follow natural and right instinct [naturalem et rectum instinctum], viz. the simple and the wise. That the wise know God is no great matter; but that the simple do is [a great matter]. But there are some who pervert the right instinct, and these people reject knowledge of God. Cf. Ps. 81: They have not known, i.e. they willed not to know, nor have they understood etc. Cf. Job. 22: They have said to God: Go away from us; we do not want your ways. But God has brought it about that through them, 
i.e. through the simple people who follow the natural instinct, are confounded those who pervert the natural instinct. By "infants" the simple are signified, cf. 1 Peter 2: Like new-born infants, reasonable, without guile. Therefore he [the Psalmist] says: Your name is admirable; but in such a way that out of the mouth of infants and nurselings you have brought praise to perfection, [you] who interiorly instigate to this; and this because of your enemies, who oppose your science and knowledge. Cf. Phil. 3: Enemies of the cross of Christ etc. ... This takes place when the simple recognize God, and others pervert the study of natural knowledge, lest they know God himself.22

Though Thomas speaks of a "natural knowledge" had by the simple, and of them following "natural instinct", he still sees this phenomenon as having its reason, its source, in a grasp of the cosmic situation. ${ }^{23}$ He sees the common man as spontaneously sizing things up, somewhat as in the $S C G$ and ST 2-2 texts.

It seems to me perfectly acceptable that the natural love which man has for God more than for his own self be seen as following from this natural knowledge of God which man has by a spontaneous, inborn reasoning to the existence of God. I think this is better than attempting to see such a primary precept as "love God above all else" merely in the way it is present in the desire for happiness.

The natural love for God above all else, even oneself, is present in every creature, but in each according to its own mode or measure. ${ }^{24}$ In the rational creature, i.e. angels and man, it is "in the mode of will". Such natural love presupposes natural intellectual knowledge of God. ${ }^{25}$ In the angel such knowledge is a mediated intuition (St. Thomas, ST, 1 1.56.3). In the human being, it is a natural conclusion, the fruit of a spontaneous, universally inborn discursive operation. Our intellectuality is "rational", as possessed of a weaker light than the angelic (St. Thomas, ST, - 1 1.58.3.)

Notice that it is inasmuch as God is known as the author of being, life, and intelligence that he cannot be hated, but must be loved (St. Thomas,
ST, ๆ 2-2.34.1). That we need a commandment concerning such love stems from the possibility (through habituation to sin) of our not living according to it in particular choices. ${ }^{26}$

My understanding is, then, that Thomas presents the existence of God as naturally known to all, even though naturally reasoned to. That someone professes ignorance of the existence of God stems from moral disorder (as the Psalms Commentary as well as the $S C G$ text asserts). I would say that this natural knowledge would fill out the picture of the commandment of love as known by virtue of itself to all. Given that one has knowledge of God as the author of being, one has knowledge of him as lovable by us, indeed as more lovable that ourselves. ${ }^{27}$

\section{Notas}

${ }^{1}$ For the point that metaphysics or primary philosophy or wisdom speaks of all things, cf. Aristotle, Metaphysics 1.2 (982a8, 21-23; b2-7, 17; 983a8-9).

${ }^{2}$ As we shall see, "law" is said of the nonrational only by way of similarity; taken too literally, "the laws of the physical world" would amount to anthropomorphism: cf. ST 1-2. 91.2.ad 3.

${ }^{3}$ ST 1-2.90.prologue; the distinction between law and grace, guidance and support, is not hard and fast: what is most truly the New Law is the grace of the Holy Spirit: 1-2.106.1. - God is extrinsic to created reality in the way that the efficient cause is other than its effect; he is so present to every creature as to be most deeply within it, because of the nature of his proper effect, the act of being; we may say that his immanence flows from his transcendence: cf. ST 1.8.1.in toto.

${ }^{4}$ ST 1-2.91 in toto. - For simplicity's sake I omit the "law of sin" (cf. 1-2.91.prologue) presented in a. 6 .

"I have spoken here of "law" along the lines that Thomas teaches concerning the positive, 
absolute names such as "goodness" and "wisdom". It is true that the word "law" suggests, when said of God, a relation to creatures. However, I take it that it is the sort of relation to creatures that is involved in all divine acts of understanding and willing of creatures. They are said of God as being in him eternally (ST 1.13.7.ad 3), and this is true of "law" also, as is clear in such texts as ST 1-2.91.1.

${ }^{6}$ The Vulgate, at Proverbs 8.22-24, has wisdom say:

[22] Dominus possedit me ab initio viarum suarum, Antequam quidquam faceret a principio. [23] Ab aeterno ordinata sum, et ex antiquis antequam terra fieret. [24] Nondum erant abyssi, et ego iam concepta eram... [The Lord possessed me from the beginning of his ways, before he had made anything, from the beginning. From eternity I was ordered, and from of old, before the earth was made. The depths were not yet, and I had already been conceived.]

${ }^{7}$ ST 1-2.91.2.ad 3. The participation by nonrational creatures in the eternal law "cannot be called 'law' save by likeness."

${ }^{8}$ ST 2-2.2.3 (ed. Ottawa, 1416a6-17). So true is this that in some texts Thomas identifies natural law simply with the natural light of reason whereby we know the difference between the good and the bad. - We read in a sermon given in Lent of 1273, entitled Collationes de decem praeceptis, and sometimes De duabus praeceptis caritatis et decem legis praeceptis, that the natural law just is the light of the human intellect conferred by God on the human being at creation:

... lex naturae; et haec nihil aliud est nisi lumen intellectus insitum nobis a deo, per quod cognoscimus quid agendum et quid vitandum. Hoc lumen et hanc legem dedit deus homini in creatione. [... the law of nature; and this is nothing else but the light of the intellect placed within us by God, through which we know what is to be done and what is to be avoided. God gave man this light and this law in creating [him]]
As described by James Weisheipl, Friar Thomas D'Aquino, Garden City, N.Y., 1974: Doubleday, "... the points in the vernacular sermon were jotted down and later written out in Latin 'after Thomas had preached"' [p. 402] by one of Thomas's secretaries, Friar Peter d'Andria [p. 319]; and so one must be prepared for a sort of "short-hand" way of speaking.

That the intellectual light spoken of here is to be identified with the agent intellect we see in such a passage as the following, from the Disputed Questions on Spiritual Creatures 10 [a work dated 1267 in Rome, according to the Leonine editor, B.-C. Bazan.]:

... we say that the light of the agent intellect about which Aristotle speaks is immediately impressed on us by God, and in function of it we distinguish the true from the false, and the good from the bad. And it is about that that the Psalm says: "The many say: who will show us good things? The light of your countenance has been stamped upon us, O Lord," i.e. [the light] through which what are good are shown to us. Thus, therefore, that which produces in us actual intelligibles, in the mode of participated light, is something of the soul and is rendered multiple in keeping with the multitude of souls and of human beings.

It should be underlined that actual knowledge of the first intelligibles and first truths is a product of abstraction from sensible experience, not something inborn; the intellectual light or agent intellect must derive information from sensible things even as regards the first notions and first truths: cf. $Q q$. de anima 5, De veritate 11.1, Quodlibet 10.4.1 [7].

${ }^{9}$ Reason as ordering towards the end is the principle of obligation here: cf. ST 1-2.90.1 and 1-2.99.1. - In so speaking I by no means wish to obscure the element of inclination which the law includes. Such inclination is, intrinsically, a sort of loyalty to the reasonable. Thus, in speaking, in ST 1-2.91.2, of the eternal law as regulating all of creation, St. Thomas speaks first of all things, inasmuch as they participate in the impression 
coming from God, as having natural inclinations towards their proper acts and goals; he goes right on to say that inasmuch as the rational creature has a more excellent participation in divine providence, as itself providing for itself and others, it too participates in the eternal law by having natural inclination to the due act and end. Yet in concluding this very passage, what Thomas points to as natural law in us is the light of natural reason by which we discern the good from the bad. The properly human inclination is rooted in the light of natural knowledge. Cf. also the treatment of our natural human "inclination" in ST 1-2.62.3, as including knowledge and appetitive movement. Cf. my paper, "Jacques Maritain and the Philosophy of Co-operation," in Alterité. Vivre ensemble differents ed. M. Gourgues and G.-D. Mailhiot, Montréal and Paris, 1986: Bellarmin/Cerf, 109-117.

${ }^{10}$ This, of course, is precisely what Thomas shows in ST 1-2.91.1 and 2. God as princeps of the universe is the supreme legislator, pronouncing the eternal law (a. 1), and natural law is a participation in the eternal law (a. 2).

${ }^{11}$ What I mean here by "natural reason" is a spontaneous reasoning process found in all humans (as will emerge in what follows).

${ }^{12}$ I think that in this matter Suarez is better than Maritain. Maritain in the posthumously published study, La loi naturelle ou loi non écrite (Texte inédit, établi par Georges Brazzola), Fribourg, Suisse, 1986: Éditions Universitaires, pp. 105-111, takes the position that the natural law depends on reason, "not on will": "Loi naturelle dépend de la Raison, non du vouloir". Thus, in his table on $\mathrm{p} .106$, he has this very explicitly. Thomas Aquinas's position is portrayed as divine reason issuing in the natural law which enters man through the natural inclinations, thus bringing us to the precepts. This seems to me quite wrong, most of all in the expression "not on will". Obviously, law, for Thomas, is an expression of reason. However, it is the work of the governor, and this providential role is presented by Thomas, very explicitly, as "what pertains simultaneously to intellect and will": cf. 1.22.prologue, and a. 1.ad 1, on God as giving precepts. Cf. also ST 1-2.97.3.ad 1: “... dicendum quod lex naturalis et divina procedit a voluntate divina..." (and cf. the entire article). Thus, also, Maritain's criticism of Suarez (in the same context) on this issue as non-Thomistic is wrong.

13 "St. Thomas, Our Natural Lights, and the Moral Order," Maritain Studies / Études maritainiennes (Ottawa) 2 (1986), 59-92 [reprinted in Angelicum 67 (1990), 285-307]. - I added to this in "Natural Law and the First Act of Freedom: Maritain Revisited," Études Maritainiennes / Maritain Studies 12 (1996), pp. 3-32.

${ }^{14} \mathrm{He}$ refers us, in nn. 57 and 58, to $S T$ 1.2.1.ad 1, In Boet. De trin. 1.3.ad 4 and to DV 22.2.

${ }^{15}$ ST 2-2.34.5:

Id autem quod est maxime et primo naturale homini est quod diligat bonum, et praecipue bonum divinum et bonum proximi.

${ }^{16}$ On friendly natural love for God more than for ourselves, cf. ST 1.60.5; whereas the love of God involved in his being our happiness might be thought of as concupiscible love: cf. $S T$ 12.2.7.ad 2.

${ }^{17}$ In EN 7.13.14, where Thomas is explaining Aristotle at 7.13 (1153b31-32):

Et potest dici quod omnes homines appetunt eamdem delectationem secundum naturalem appetitum, non tamen secundum proprium iudicium; non enim omnes existimant corde, neque dicunt ore eamdem delectationem esse optimam, natura tamen omnes inclinat in eandem delectationem sicut in optimam, puta in contemplationem intelligibilis veritatis, secundum quod omnes homines natura scire desiderant. Et hoc contingit, quia omnia habent naturaliter in se ipsis quiddam divinum, scilicet inclinationem naturae, quae dependet ex principio primo; vel etiam ipsam formam, quae est huius inclinationis principium.

${ }^{18}$ In n. 58 he refers to $S C G 3.38$. In n. 57 he mentioned in more detailed fashion ST 1-2.89.6. I notice that $\mathrm{F}$ presents the topic of 1-2.89.6 as 
whether it is possible for a youth to sin venially before sinning mortally. The topic is rather whether one can have only original sin and venial sin on one's soul (no mortal sin). The answer is no. The idea is that before one can commit a venial sin one must either get rid of original sin or one will commit a mortal sin. Thus, it is quite possible, according to the doctrine, to sin venially before sinning mortally. This is so, if one first turns to God, thus eliminating original sin, and then sins venially. The doctrine in this text, with its ad 3 about the obligation to turn to God at the very start of the moral life, I would say should be read in the light of the doctrine of natural reasoning that I mention below. However, Cajetan read it as requiring one to recognize, through deliberation, only the bonum honestum as such (as one's proper end), rather than actual knowledge of and turning to God; cf. my paper: "Natural Law and the First Act of Freedom: Maritain Revisited", Études Maritainiennes /Maritain Studies 12 (1996), pp. 3-32, in the section on Cajetan ca n. 27.

${ }^{19}$ Thomas Aquinas, Sententia libri ETHICORUM Aristotelis 6.5 (ed. Leonine, t. 47-2, Rome, 1969: Ad Sanctae Sabinae, lines 102-106 (concerning Aristotle at 1141a12-17) (ed. Pirotta, \#1181):

... existimamus quosdam esse sapientes totaliter, idest respectu totius generis entium... illa quae est sapientia simpliciter est certissima inter omnes scientias, inquantum scilicet attingit ad prima principia entium, quae secundum se sunt notissima, quamvis aliqua illarum, scilicet immaterialia, sunt minus nota quoad nos. Universalissima autem principia sunt etiam quoad nos magis nota, sicut ea quae pertinent ad ens inquantum est ens: quorum cognitio pertinet ad sapientiam sic dictam, ut patet in quarto Metaphysicae. [my italics] and Thomas, $C M$ Prologue:

... illa scientia maxime est intellectualis, quae circa principia maxime universalia versatur. Quae quidem sunt ens, et ea quae consequuntur ens, ut unum et multa, potentia et actus.

${ }^{20}$ St. Thomas describes this as the maximally first principle: cf. $C M$ 3.5.6.
${ }^{21}$ This work is presented by James Weisheipl, Friar Thomas D'Aquino: His Life, Work, and Thought, Garden City, N.Y., 1974: Doubleday and Co., pp. 368-369 and pp. 302-304, as Postilla super Psalmos. Ps. 1-54 (Naples, 1272-1273). He explains that the given title reflects the use of the psalms in the liturgy of the Church, but that Thomas is really writing what would be more properly and simply described as Super Psalmos (incomplete). [p. 303]. Speaking of the period Sept. 29, 1272 to December 6 1273, from the beginning of the academic year 1272-1273 to the moment in the following term when Thomas stopped writing, Fr. Weisheipl says that "this is the only academic work that can be attributed to this period with certainty." [p. 302] By "academic work" here is meant actual lecturing; the Super Psalmos is a reportatio by Reginald of Piperno, Thomas's personal secretary.

${ }^{22}$ The commentary continues, speaking of the celestial phenomena as the ground of the natural reasoning, in keeping with the text of the psalm:

Next, he subjoins the reason for this manifestness, saying Because [Quoniam]. Tully says in the book De natura deorum, and it was said also by Aristotle, though in those books of his that we have among us it is not found, that if some man were to enter a palace, which he would see [to be] well disposed, none is so lacking in intellect [amens] that, even though he would not see how it had been made, he would not perceive that it had been made by someone. And this the order of the celestial bodies especially shows. For there were some who, erring, attributed the causes of things to the necessity of matter: hence, they said all had been made because of the warm, the cold, the dry, and the wet: as by the elements which have these properties. But this, if it can have an appearance [of truth] regarding other things, can in no way [have such appearance] in [the case of] the celestial bodies; for they cannot be attributed to the necessity of matter, where one is so distant from the other, and they take so great a time to complete their course. That cannot be traced back to anything but an 
intelligent cause. And so Scripture, when it wants to manifest the power of God, directs us to a consideration of the heavens....

${ }^{23}$ Clearly the presentations in the $S C G$ and the In Psalm. relate to Thomas's "fifth way" of proving the existence of God (ST 1.2.3). It is also notable that it is this line of thinking, purpose as opposed to chance as a source of the cosmos, which is presented in Thomas's popular sermons on the Apostles' Creed, concerning the existence of a God. Cf. In Symbolorum Apostolorum expositio, in Opuscula theologica, t. II, ed. R. Spiazzi, O.P., Rome and Turin, 1954: Marietti, \#869. Here Thomas insists on the regularity of the celestial movements. This work also dates from 1273, in Naples. And once again, Thomas speaks of the rarety and stupidity of people who do not believe that the cosmos is governed.

${ }^{24}$ Notice that Thomas carefully presents this doctrine three times in the $S T$, viz. at 1.60.5, at 12.109.3, and at 2-2.26.3.

${ }^{25}$ Notice first of all the argument sed contra of ST 1.60.1. - In ST 1.60.1 it is seen that natural love is present in each creature according to its own mode, and that for angels and men, this is "secundum voluntatem". In 1.59.1 it was seen that will is the most perfect mode of inclination towards the good, in that it follows upon the intellectual vision of goodness, considered universally. In 1.60.5.ad 1 it is seen that all naturally love God more than themselves, each in its own mode (and notice that the sed contra there links this love to the natural law).

${ }^{26}$ Cf. ST 1-2.99.2.ad 2:

$\ldots$ it is to be said that it was fitting for the divine law that it provide for man not only as to those matters which are beyond the capacity of reason, but also as to those concerning which it does occur that human reason suffer impediment. Now, human reasion concerning the moral precepts, as regards the most common precepts of the natural law, could not err, taking them universally, but nevertheless, because of habituation in sinning, it has been obscured regarding particular things to be done...

Cf. also $S T$ 1-2.100.5.ad 1, as to why the ten commandments speak of our duty to God and to our neighbor, but not of our duty to ourselves:

... the precepts of the decalogue are related to the precepts of love. But a precept had to be given to man concerning the love of God and neighbor because in that respect the natural law had been obscured because of sin; not as regards the love of himself, because in that respect the natural law was still in vigour...

Cf. also 1-2.109.3, on our natural love for God above all else, and the effect of original sin.

${ }^{27}$ As I have often pointed out, the first level of natural inclinations spoken of in ST 1-2.94.2 is the natural inclination common to all creatures; it is not ordered merely towards the preservation of the individual self. It covers everything spoken of in ST 1.60 as natural love: love of the individual self, love of one's species more than the individual self, and love of God more than oneself or any creature. The second level of inclination in that text is not about reproduction, for that is common to all substances, but about the perfect animal mode of reproduction. The third level is not about love of God, but about seeking the truth about God, as well as living in society: the rational animal by nature desires to know, and especially to know the truth concerning God.

\section{References}

Flannery, K. (2001) Acts Amid Precepts: The Aristotelian Logical Structure of Thomas Aquinas's Moral Theory, Washington, DC: CUA Press.

Suarez, F. (1856a). Opera omnia. París: Carolus Berton.

Suarez, F. (1856b). An lex naturalis sit lex divina praeceptiva. En F. Suarez (Ed.), De lege aeterna, et naturali, ac jure gentium (pp. 104-112). París: Carolus Berton. 
